\title{
BODY SIZE AND FLIGHT DISTANCE IN STINGLESS BEES (HYMENOPTERA: MELIPONINI): INFERENCE OF FLIGHT RANGE AND POSSIBLE ECOLOGICAL IMPLICATIONS
}

\author{
ARAÚJO, E. D., ${ }^{1}$ COSTA, M., ${ }^{2}$ CHAUD-NETTO, J. ${ }^{2}$ and FOWLER, H. G. ${ }^{3}$ \\ ${ }^{1}$ Grupo de Pesquisa em Comportamento Animal, ITP, UNIT, CEP 49032-490, Aracaju, SE, Brazil \\ ${ }^{2}$ Departamento de Biologia, Instituto de Biociências, UNESP, Av. 24-A, 1515, C.P. 199, \\ CEP 130506-900, Rio Claro, SP, Brazil \\ ${ }^{3}$ Departamento de Ecologia, Instituto de Biociências, UNESP. Av. 24-A, 1515, C.P. 199, \\ CEP 130506-900, Rio Claro, SP, Brazil \\ Correspondence to: Edilson D. Araújo, Laboratório de Zoologia, ITP, UNIT, \\ CEP 49032-490, Aracaju, SE, Brazil, e-mail: edaraujo@yahoo.com.br \\ Received February 4, 2003 - Accepted April 30, 2003 - Distributed August 31, 2004
}

(With 2 figures)

\begin{abstract}
We examined the spatial implications of maximum flight distance for several species of stingless bees. Data suggested that maximum flight distance in Meliponini is a function of body size, especially generalized wing size, which can be estimated through principal component analysis. For six species of stingless bees, flight distances and generalized wing sizes were highly correlated $(r=0.938)$. This indicates that species of Meliponini occupy an effectively larger area as body size increases, which has important implications in the spatial dynamics of local populations restricted to forest fragments. We also used the fitted linear regression model to estimate the maximum flight distance for 12 other species of Meliponini. The results of this research may provide insights for future studies of biological conservation.
\end{abstract}

Key words: flight distance, local populations, morphometry, multivariate analysis.

\section{RESUMO}

Tamanho do corpo em Meliponini (Hymenoptera: Apidae): inferência do raio de vôo e possíveis implicações ecológicas

Neste trabalho analisamos as implicações espaciais da distância máxima de vôo para algumas espécies de meliponíneos. Os dados sugerem que a distância máxima de vôo em meliponíneos está relacionada ao tamanho do corpo, especialmente ao tamanho generalizado das asas, que pode ser estimado utilizando análises de componentes principais. Uma análise utilizando seis espécies de meliponíneos evidenciou que o tamanho generalizado das asas está fortemente correlacionado à distância de vôo $(r=0,938)$. Isso sugere que espécies de meliponíneos ocupam área efetivamente maior quanto maior for o tamanho do corpo, trazendo importantes implicações para a dinâmica espacial de populações locais restritas a áreas fragmentadas. Neste trabalho, também utilizamos um modelo de regressão linear a fim de estimar as distâncias máximas de vôo para 12 outras espécies de meliponíneos. Esta pesquisa fornece subsídios para futuros estudos relacionados à conservação da biodiversidade.

Palavras-chave: distância de vôo, populações locais, morfometria, análise multivariada. 


\section{INTRODUCTION}

Meliponini are eusocial bees which are abundant in subtropical and tropical regions of the world, and comprise one of the most diverse and important insect groups. The stingless bees have an important ecological role, especially in the pollination of a large fraction (40\% to $90 \%$ ) of the plants forming Brazilian forests (Kerr et al., 1994).

Data of maxima flight distances of stingless bee workers are important for tropical ecosystems (Roubik \& Aluja, 1983) and may even be used to formulate models of population dynamics of different species. Studies of flight distances, in conjunction with other studies of local populations, can generate important inferences on migration, colonization, forest fragmentation, and biodiversity conservation.

Flight distances have been studied for only a few stingless bee species and generally utilize indirect methods of release and recapture (Roubik, 1989). Apparently, there is no directional interference in flight activities, and the number of marked honey bees (Apis mellifera) collected declines linearly in relation to distance from the colonies (Paranhos et al., 1997). There is an apparent positive correlation between body size, especially wing area, and flight distances (Casey et al., 1985; Byrne et al., 1988). Schwarz (1948) suggested that, because they strengthen wing stability, wing hamuli in greater number are associated with larger flight capacity.

Worker bee size reflects an adaptation to environmental conditions (Ruttner, 1988). A major part of the morphological variation in Meliponini occurs independently of phylogeny due to the fact that, for social bees, worker body size has been generally considered as an adaptation to foraging activity and floral resource exploitation (Roubik \& Ackerman, 1987; Baumgartner \& Roubik, 1989). About 75.5\% of body size variation in Meliponini corresponds to adaptive factors associated with resource exploitation (Pignata \& Diniz-Filho, 1996). Here we examine the spatial implications of maximum flight distance for several species of stingless bees.

\section{MATERIAL AND METHODS}

Variation in worker body size of six species of Meliponini was studied using principal component analysis (PCA) based on covariance matrices. The PCA uses the original variable set and performs an orthogonal analysis to transform it into a new non-correlated variable set, whose variances decline in each principal component, in such a way that the first principal component explains the major part of the variance present in the original characters (Reis et al., 1988). A logarithmic data transformation is generally used to correct for nonlinearity produced by the allometry among differing morphological characters (Gould, 1966; Neff \& Marcus, 1980). Species studied and their identification codes were: (Pb) Plebeia droryana Friese (1900), (Ts) Trigona spinipes Fabricius (1793), (Mc) Melipona compressipes Fabricius (1804), (Mq) Melipona quadrifasciata Lepeletier (1836), (Mm) Melipona marginata Lepeletier (1836), and (Cc) Cephalotrigona capitata Smith (1854), which were chosen because flight distances for these bees can easily be found in the literature.

Morphometric characters were measured using the criteria of Cunha $(1973,1991)$ and are given in Table 1, as well as the respective score for each of the six species studied.

Flight distance data were taken from publications which used mark-recapture methods. Roubik \& Aluja (1983) used a magnetic recapture method and through regression analysis concluded that the maximum flight distance for workers of Cephalotrigona capitata was 1,650 m. In Melipona marginata, maximum flight distance is $800 \mathrm{~m}$. (Wille, 1983). Kerr (1987) recorded a flight distance of 2,000 $\mathrm{m}$ for Melipona quadrifasciata; 840 $\mathrm{m}$ for Trigona spinipes; $2,470 \mathrm{~m}$ for Melipona compressipes; and $540 \mathrm{~m}$ for Plebeia droryana.

Two principal component analyses were performed. One analysis used generalized body size, employing all the morphometric variables; the other used only wing variables. First principal component scores, for each of these analyses, together with the flight distances for each species, were used to form two new matrices which were examined with a linear regression analysis (Zar, 1999). A third regression analysis was performed using log values of the number of wing hamuli for each of the six species studied in relation to their respective flight distances.

Upon fitting of the linear regression model, a new matrix was created with data from the 11 characters of the wing (characters number 18 to 28 of Table 1) of 12 other species of Meliponini. This new covariance matrix, following the same pattern as in the previous analysis, was converted into 11 log-transformed characters and subjected to a PCA. 
TABLE 1

Measured morphological characters and their scores in the six stingless bee species analyzed (P. droryana - Pd, $T$. spinipes - Ts, M. compressipes - Mc, M. quadrifasciata - Mq, M. marginata - Mm, and C. capitata-Cc).

\begin{tabular}{|c|c|c|c|c|c|c|c|}
\hline $\mathbf{N}$ & Character & Pd & Ts & Mc & Mq & Mm & $\mathrm{Cc}$ \\
\hline 1 & Length of the antennal flagellus & 1.125 & 1.825 & 3.100 & 2.835 & 0.975 & 2.425 \\
\hline 2 & Scape length & 0.525 & 0.925 & 1.500 & 1.400 & 1.025 & 1.225 \\
\hline 3 & Mandibular length & 0.525 & 0.925 & 1.575 & 1.550 & 1.025 & 1.175 \\
\hline 4 & Inter-malar distance & 0.800 & 1.250 & 1.625 & 1.500 & 1.125 & 1.400 \\
\hline 5 & Glossa length & 0.950 & 1.800 & 2.765 & 2.475 & 1.875 & 2.125 \\
\hline 6 & $\begin{array}{l}\text { Distance between the central ocellus and the clypeus } \\
\text { along the frontal line }\end{array}$ & 0.850 & 1.550 & 2.500 & 2.375 & 1.625 & 2.200 \\
\hline 7 & Inter-ocular distance at the central ocellus & 0.625 & 1.325 & 2.275 & 1.800 & 1.375 & 1.450 \\
\hline 8 & Inter-ocular distance along the frontal-clypeus suture & 0.400 & 0.500 & 1.175 & 1.225 & 0.925 & 0.950 \\
\hline 9 & Clipeal length & 0.200 & 0.350 & 0.575 & 0.475 & 0.325 & 0.450 \\
\hline 10 & Inter-alveolar distance & 0.300 & 0.450 & 0.700 & 0.600 & 0.500 & 0.525 \\
\hline 11 & Distance between lateral ocelli & 0.225 & 0.525 & 0.725 & 0.750 & 0.400 & 0.625 \\
\hline 12 & $\begin{array}{l}\text { Distance between the lateral ocellus and the } \\
\text { compound eye }\end{array}$ & 0.950 & 1.800 & 2.800 & 2.125 & 1.625 & 0.875 \\
\hline 13 & Femur length & 1.250 & 2.800 & 3.750 & 3.220 & 2.150 & 1.225 \\
\hline 14 & Tibial length & 0.425 & 0.875 & 1.425 & 1.125 & 0.850 & 0.500 \\
\hline 15 & Maximum width of the tibia & 0.650 & 1.125 & 1.950 & 1.625 & 1.175 & 0.475 \\
\hline 16 & Basitarsal length & 0.275 & 0.575 & 1.000 & 0.825 & 0.550 & 0.275 \\
\hline 17 & Maximum width of the basitarsus & 3.600 & 6.900 & 9.200 & 7.800 & 5.400 & 7.900 \\
\hline 18 & Maximum length of the fore wing & 1.350 & 2.475 & 3.250 & 2.900 & 1.925 & 2.905 \\
\hline 19 & Maximum width of the fore wing & 0.925 & 1.500 & 1.800 & 1.300 & 1.000 & 1.900 \\
\hline 20 & M nerve length & 0.100 & 0.075 & 0.300 & 0.225 & 0.150 & 0.100 \\
\hline 21 & Rs nerve length & 1.000 & 1.750 & 2.870 & 2.425 & 1.725 & 2.200 \\
\hline 22 & Anal nerve length & 0.950 & 1.800 & 2.590 & 2.475 & 1.650 & 2.150 \\
\hline 23 & $\mathrm{M}+$ cubital nerve length & 0.750 & 1.350 & 1.820 & 1.350 & 1.000 & 1.650 \\
\hline 24 & Cubital nerve length & 0.225 & 0.375 & 0.550 & 0.475 & 0.325 & 0.450 \\
\hline 25 & Cubital transverse nerve length & 0.100 & 0.200 & 0.350 & 0.300 & 0.175 & 0.200 \\
\hline 26 & Cubital + anal nerve length & 2.695 & 4.600 & 6.600 & 6.000 & 3.950 & 5.500 \\
\hline 27 & Maximum length of the hind wing & 0.675 & 1.150 & 1.775 & 1.450 & 1.000 & 1.225 \\
\hline 28 & Maximum length of the fore wing & 0.125 & 0.125 & 0.350 & 0.250 & 0.250 & 0.200 \\
\hline 29 & Number of hamuli & 1.050 & 1.750 & 3.150 & 3.080 & 2.000 & 2.400 \\
\hline 30 & Maximum length between tegula & 0.975 & 1.375 & 3.150 & 2.940 & 1.825 & 1.775 \\
\hline 31 & Maximum length of the mesoscutum & 0.300 & 0.575 & 1.050 & 0.375 & 0.625 & 0.550 \\
\hline 32 & Maximum length of the scutellum & 1.119 & 1.390 & 3.867 & 3.320 & 2.340 & 2.907 \\
\hline
\end{tabular}

The character scores of the first principal component were subjected to the same linear regression model as before, which was then used to estimate the maximum flight distance for each of these 12 species. Analyses were performed using SYSTAT, version 5.01 for Windows.

\section{RESULTS}

Estimated flight distances for the six species of Meliponini and the scores of the principal component analysis were used to form two new matrices. Scores from the first principal component for the 32 
morphological characters represented the speciesspecific generalized body size, which was highly correlated with data of flight distances $(r=0.897)$. A linear regression analysis indicated that more than $75 \%$ of the variation in the maximum flight distance could be attributed to generalized worker body size (adjusted $\mathrm{R}^{2}=0.755$ ). We then examined the logtransformed values of the number of hamuli, which produced a fit with maximum flight distance similiar to that obtained for generalized body size (adjusted $\left.R^{2}=0.757\right)$. These results are, however, congruent with the suggestion of Schwarz (1948) that a greater number of wing hamuli is associated with larger flight capacity. However, when we performed a linear regression analysis using only scores of species-specific generalized wing size, these were highly correlated with maximum flight distance $(\mathrm{r}=0.938)$ (Fig. 1). Therefore, more than $84 \%$ of the maximum flight distance variation can be explained by generalized wing size (adjusted $R^{2}=0.849$ ). This suggests that, as in the Euglossinae (Casey et al., 1985) and in Homoptera (Byrne et al., 1988), Meliponini wing size explains a large fraction of maximum flight capacity.

Using the fitted linear regression, maximum flight distance $=1,383.333+645.185$ (generalized wing size) + error, we estimated the maximum flight distance for 12 additional species of Meliponini from their generalized wing size. For small bees Tetragonisca angustula Latreille (1836), Scaura latitarsis Friese (1900), Plebeia poecilochroa Moure \& Camargo (1993), and Nannotrigona testaceicornis Lepeletier (1836), maximal flight distances ranged from 621 to $951 \mathrm{~m}$ (Fig. 2). Maximal flight distances for medium-sized species Trigona hypogea Silvestri (1902), Trigona recursa SMITH (1863), Geotrigona inusitata Moure \& Camargo (1991), Frieseomelitta varia Lepeletier (1836), Partamona cupira Smith (1863) and Scaptotrigona postica Latreille (1807) ranged from 1159 to $1710 \mathrm{~m}$ (Fig. 2). Estimated flight distances for larger bees Melipona bicolor Lepeletier (1836) and Melipona scutellaris Latreille (1811), were greater than $2 \mathrm{~km}$ (Fig. 2). It should be pointed out that each estimated value represents a mean expectation of the maximum flight distance for each species, with an associated error.

\section{DISCUSSION}

These data suggest further need for research of the spatial dynamics of local populations of Meliponini. Paranhos et al. (1997) observed that colonies of Apis mellifera show no directional interference in flight activities. This indicates that each colony occupies a central position in relation to flight radius, defining an effective area corresponding to the circumference described by the medium flight radius in their components.

Our results also suggest that stingless bees occupy a maximum effective space proportional to body size, especially with wing dimensions, which might constitute strong constraints on local populations restricted to forest fragments. Habitat fragmentation occurs when a large continuous area is reduced, creating one or more habitat fragments (Lovejoy et al., 1986; Wilcove et al., 1986). These fragments of the original habitat are frequently isolated by degraded and highly modified areas. When a habitat is fragmented, dispersion and potential colonization is frequently reduced. Many species of birds, mammals, and insects of the interior forest will not cross small distances of open areas (Lovejoy et al., 1986; Bierregaard et al., 1992).

In the Meliponini, genetic drift is an extremely important factor in the isolation of small local populations. Araújo (2000) suggested that populations of Melipona are particularly sensitive to the effects of genetic drift due to homozygosity in the Xo sex determination locus. Carvalho et al. (1995) documented the loss of alleles and the extinction of local populations due to low population number. Kerr \& Vencovsky (1982) estimated that a Meliponini population should contain a minimum of 44 colonies to lower the risks of rapid extinction.

Our results suggest that the risk of extinction is greater for smaller stingless bees. Colonies of Plebeia droryana would be effectively isolated if inter-fragment distances were greater than $600 \mathrm{~m}$. On the other hand, larger species, such as Melipona compressipes and Melipona quadrifasciata, would be effectively isolated if forest fragments were greater than $2 \mathrm{~km}$ apart. However, larger species theoretically have a greater capacity to migrate between forest fragments, but would also depend upon larger areas to persist.

In the stingless bees, body size could act as a limiting factor in maximum flight capacity. Nevertheless, it is possible that many species in fact occupy an effectivly smaller space, depending on the influence of other variables such as: foraging behavior related to specialization in the search for specific floral resources, manners of orientation and trail laying, localization and abundance of food 
resources, and availability of nest sites, among others. Swarming activity in Meliponini could also act as a limiting factor of the spatial distribution of nests, since a new colony of meliponins is strongly dependent on the parental nest from which stingless bees generally provide the new nest with food and materials (Nogueira-Neto, 1997). Therefore, maximum flight distance, conditioned by body size, must have a direct influence on the dispersion capacity of the population.

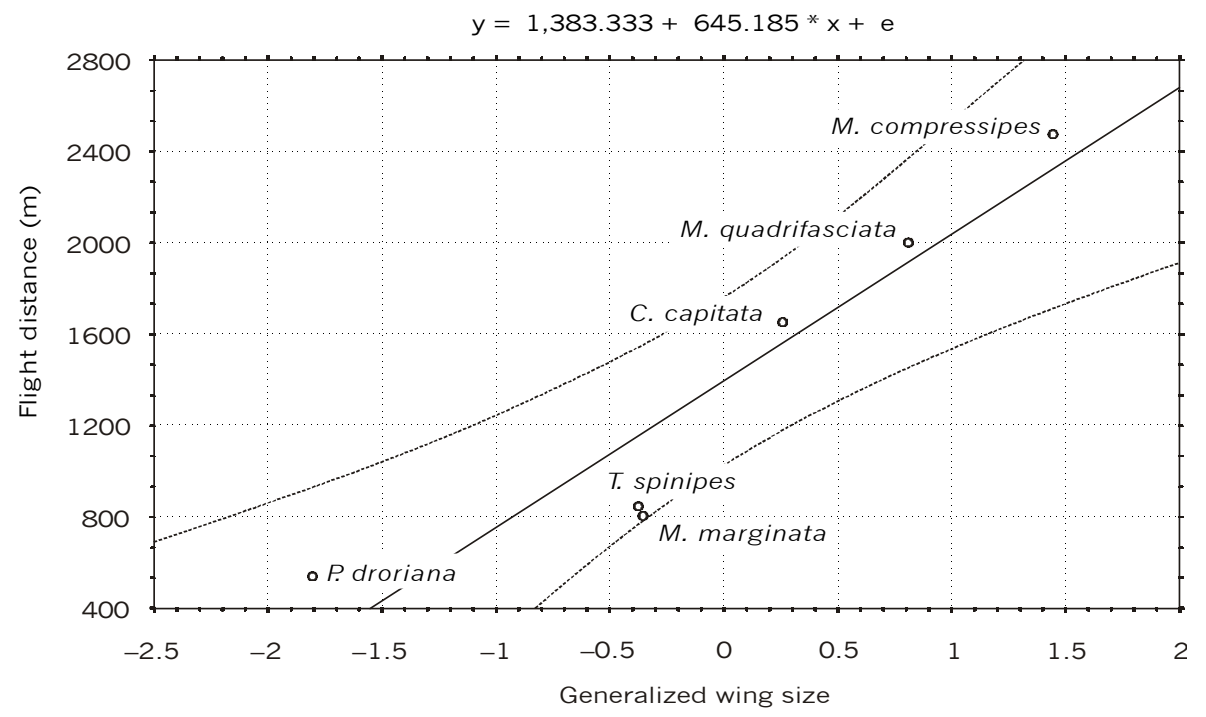

Fig. 1 - Linear regression of generalized wing size (from the first principal component) against maximum flight distance for several species of stingless bees. Dotted lines represent confidence intervals $(\alpha=0.05)$.

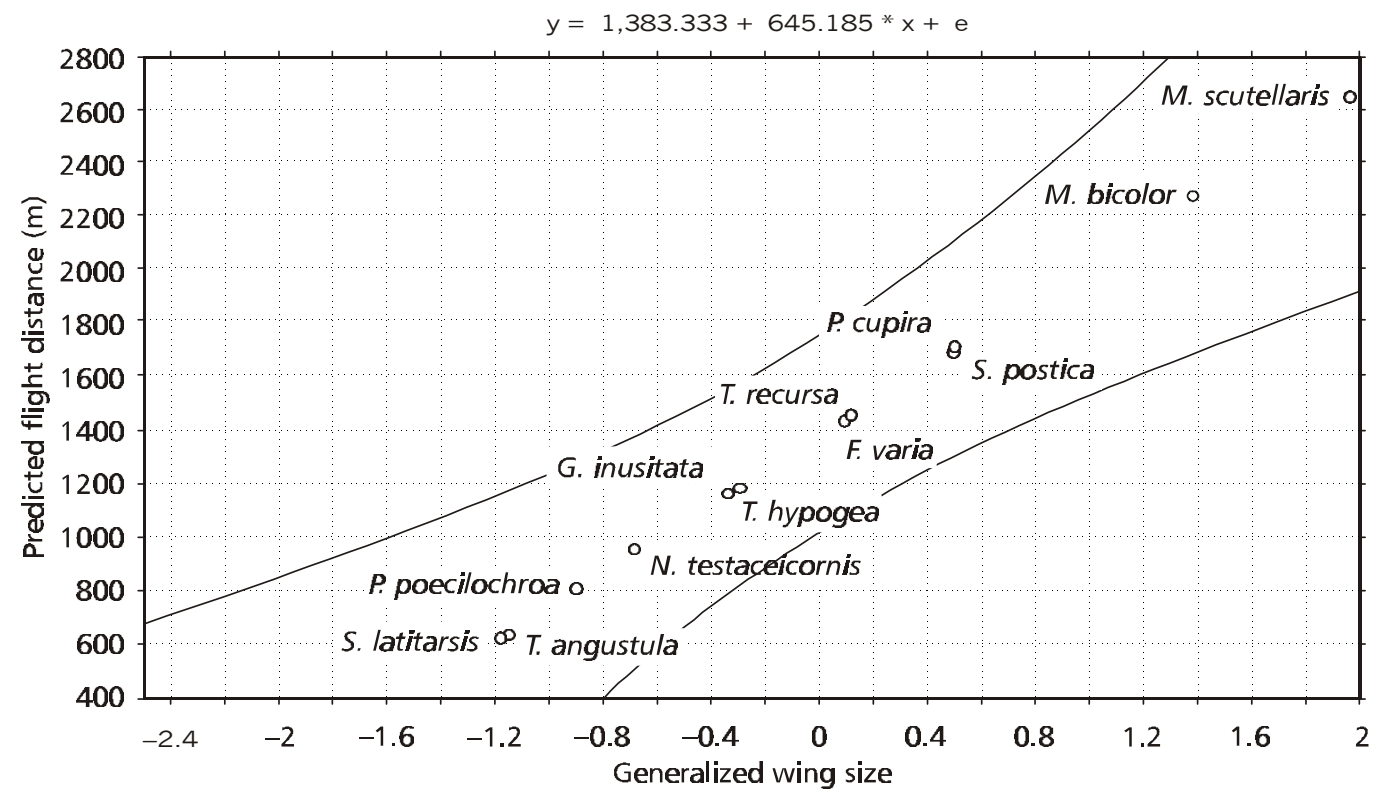

Fig. 2 - Maximum flight distances for 12 species of Meliponini estimated using a linear regression model. Dotted lines show the confidence interval $(\alpha=0.05)$, based upon the linear regression of six documented species (Fig. 1). 
With respect to biodiversity conservation in tropical forest fragments, the differential extinction of stingless bee species, due to physical limitations of dispersion constrained by body size, could lead to a change in plant abundance and diversity because stingless bees are one of the principal pollination agents of tropical forest species. Velthuis (1997) estimated that $33 \%$ of plant species in the Atlantic rainforest are exclusively pollinated by Meliponini. In spite of the fact that stingless bees are not specific pollinators, pollination tendencies exist for specific species and there is even a clear distinction between species that pollinate different forest strata (Velthuis, 1997). Within this context, the fact that a strong correlation exists between body size and flight distance in Meliponini can be of use in working to conserve tropical biodiversity.

Acknowledgements - We thank Prof. Dr. José Alexandre Felizola Diniz Filho for helpful discussions and suggestions, to CAPES for the doctoral fellowship awarded to the first author, and an anonymous reviewer for suggestions and comments on an earlier version of the manuscript.

\section{REFERENCES}

ARAÚJO, E. D., 2000, Extinção em populações do gênero Melipona (Hymenoptera: Meliponinae): efeito do tamanho populacional e da produção de machos por operárias. Naturalia, 25: 287-299.

BAUMGARTNER, D. L. \& ROUBIK, D. W., 1989, Ecology of necrophilous and filth-gathering stingless bees (Apidae: Meliponinae) of Peru. J. Kans. Entomol. Soc., 62: 11-22.

BIERREGAARD JR., R. O., LOVEJOY, T. E., KAPOS, V., DOS SANTOS, A. A. \& HUTCHINGS, R. W., 1992, The biological dynamics of tropical rainforest fragments. Bio-Science, 42 : 859-866.

BYRNE, D. N., BUCHMANN, S. L. \& SPANGLER, H. G., 1988, Relationship between wing loading, wingbeat frequency and body mass in homopterous insects. J. Exp. Biol., 135: 9-24.

CARVALHO, G. A., KERR, W. E. \& NASCIMENTO, V. A., 1995, Sex determination in bees. XXXVII. Decrease of Xo heteroalleles in a finite population of Melipona scutellaris. (Apidae, Meliponini). Brazil. J. Genet., 18: 13-16.

CASEY, T. M., MAY, M. L. \& MORGAN, K. R., 1985, Flights energetics of euglossinae bees in relation to morphology and wing stroke frequency. J. Exp. Biol., 116: 571-289.

CUNHA, R. A., 1973, Taxonomia numérica de alguns Meliponinae (Hymenoptera, Apidae). Ciênc. Biol., 1: 25-42.

CUNHA, R. A., 1991, Revisão da taxonomia de alguns Meliponinae por métodos fenéticos (Hym., Apidae). Naturalia, 16: 33-53.

GOULD, S. J., 1966, Allometry and size in ontogeny and phylogeny. Biol. Rev., 41: 587-640.
KERR, W. E., 1987, Biologia, manejo e genética de Melipona compressipes fasciculata Smith (Hymenoptera, Apidae). Tese (Professor Titular), Universidade Federal do Maranhão, São Luiz, 141p.

KERR, W. E. \& VENCOVSKY, R., 1982, Melhoramento genético em abelhas I. Efeito do número de colônias sobre o melhoramento. Brazil. J. Genet., 2: 279-285.

KERR, W. E., NASCIMENTO, V. \& CARVALHO, G. A., 1994 Há salvação para os meliponíneos?, pp. 60-64. In: R. Zucchi, P. M. Drumond, P. G. Fernandes-da-Silva \& S. C. Augusto (eds.), Anais do lo Encontro sobre aAbelhas de Ribeirão Preto. Universidade de São Paulo, FFCLRP, Ribeirão Preto.

LOVEJOY, T. E., BIERREGAARD Jr., R. O., RYLANDS, A. B., MALCOLM, J. R., QUINTELA, C. E., HARPER, L. H., BROWN JR., K. S., POWELL, A. H., POWELL, G. V. N., SCHUBART, H. O. R. \& HAYS, M. B., 1986, Edge and other effects of isolation on amazon forest fragments, pp. 257 285. In: M. E. Soulé (ed.), Conservation biology: the science of scarcity and diversity. Sinauer, Sunderland.

NEFF, N. A. \& MARCUS, L. F., 1980, A survey of multivariate statistical methods of systematics. Neff \& Marcus, New York.

NOGUEIRA-NETO, P., 1997, Vida e criação de abelhas indigenas sem ferrão. Nogueirapis, São Paulo.

PARANHOS, B. A. J., WALDER, J. M. M. \& CHAUD-NETTO, J., 1997, Flight range of africanized honeybees, Apis mellifera L. 1758 (Hymenoptera: Apidae) in an apple grove. Scientia Agrícola, 54: 85-88.

PIGNATA, M. I. B. \& DINIZ-FILHO, J. A. F., 1996, Phylogenetic autocorrelation and evolutionary constraints in worker body size of some neotropical stingless bees (Hymenoptera, Apidae). Heredity, 76: 222-228.

REIS, S. F., CRUZ, J. F. \& VON ZUBEN, C. J., 1988, Análise multivariada da evolução craniana em roedores caviídios: convergência de trajetórias ontogenéticas, Brazil. J. Genet., 11: 633-641.

ROUBIK, D. W., 1989, Ecology and natural history of tropical bees. Cambridge University Press, Cambridge.

ROUBIK, D. W. \& ALUJA, M., 1983, Flight ranges of Melipona and Trigona in tropical forest. J. Kans. Entomol. Soc., 56: 217-222.

ROUBIK, D. W. \& ACKERMAN, J. D., 1987, Long-term ecology of euglossine orchid-bees in Panamá. Oecologia, 73: 321-333.

RUTTNER, F., 1988, Biogeography and taxonomy of honeybee. Springer-Verlag, New York.

SCHWARZ, H. F., 1948, Stingless bees (Meliponinae) of the western hemisphere. Bull. Am. Mus. Nat. Hist., 90: 1-546.

VELTHUIS, H. H. W. (org.), 1997, Biologia das abelhas sem ferrão. Congresso Centenário da Apimondia, Antverpia.

WILCOVE, D. S., MCLELLAN, C. H. \& DOBSON, A. P., 1986, Habitat fragmentation in the temperate zone, pp. 237-257. In: M. E. Soulé (ed.), Conservation biology: the science of scarcity and diversity. Sinauer, Sunderland.

WILlE, A., 1983, Biology of the stingless bees. Annu. Rev. Entomol., 28: 41-64.

ZAR, J. H., 1999, Biostatistical analysis. Prentice-Hall, New Jersey. 